\title{
Proangiogenic neutrophilic-myeloid-derived suppressor cells emerge via two parallel pathways in renal cell carcinoma and melanoma
}

\author{
Jennifer Ko ${ }^{*}$, Patricia Rayman, Dana Obery, Daniel Lindner, Ernest Borden, James Finke \\ From Society for Immunotherapy of Cancer 28th Annual Meeting \\ National Harbor, MD, USA. 8-10 November 2013
}

Targeted therapy including anti-angiogenic therapy, kinase inhibitors, and immunotherapy dominate cancer drug development in renal cell carcinoma (RCC) and malignant melanoma (MM), where traditional methodologies have failed. Myeloid-derived suppressor cells (MDSC) may represent a mode of resistance to such treatments and require investigation in human patients. Here we explore the relationship between conventional neutrophils and neutrophilic-MDSC (nMDSC) in RCC and MM. We show that T-cell suppressive nMDSC consist of hypodense CD11b+CD15+CD14- immature CD16- myelocytes/metamyelocytes and mature CD16+ neutrophils co-precipitating with peripheral blood mononuclear cells (PBMCs) in patient blood $(n=22)$ and tumors $(n=16)$. Such cells were not significantly present in healthy blood donors $(n=5)$. In parallel, conventional neutrophils co-precipitating with red blood cells (RBCs) were found to be uniquely immunosuppressive when isolated from RCC or MM patients $(n=8)$, but not when isolated from healthy blood donors $(\mathrm{n}=5)(\mathrm{p}<0.05)$. Both hypodense n-MDSC as well as conventional neutrophils from cancer patients expressed increased levels of proangiogenic molecules $(n=4)$ and enhanced tumorassociated angiogenesis of RCC and MM xenografts in nude mice $(\mathrm{p}<.0001)$. This functional shift in mature neutrophils was modeled in vitro upon exposure of healthy donor derived neutrophils to tumor cell conditioned medium; and, was associated with an increase in neutrophil production of immunosuppressive arginase and reactive oxygen species, as well as an increase in proangiogenic molecule expression and in vivo angiogenic activity $(\mathrm{n}=3, \mathrm{p}<.0001)$. The data support a role for nMDSC that are both T-cell suppressive and pro-angiogenic in RCC

Cleveland Clinic, Cleveland, OH, USA

( 2013 Ko et al; licensee BioMed Central Ltd. This is an Open Access article distributed under the terms of the Creative Commons Attribution License (http://creativecommons.org/licenses/by/2.0), which permits unrestricted use, distribution, and reproduction in any medium, provided the original work is properly cited. and MM cancer patients. Furthermore, our experiments suggest that $n$-MDSC arise via the parallel premature egress of bone marrow myeloid precursors as well as a functional switch in conventional neutrophil activity in cancer patients. Such activity is at least in part mediated via soluble tumor-derived factors which may circulate in patient blood. Ancillary strategies targeting myeloid cells may be an important part of future clinical trials to enhance the potency of targeted therapy.

Published: 7 November 2013

doi:10.1186/2051-1426-1-S1-P159

Cite this article as: Ko et al:: Proangiogenic neutrophilic-myeloid-

derived suppressor cells emerge via two parallel pathways in renal cell carcinoma and melanoma. Journal for ImmunoTherapy of Cancer 20131 (Suppl 1):P159.

Submit your next manuscript to BioMed Central and take full advantage of:

- Convenient online submission

- Thorough peer review

- No space constraints or color figure charges

- Immediate publication on acceptance

- Inclusion in PubMed, CAS, Scopus and Google Scholar

- Research which is freely available for redistribution 